Julita Orzelska*

ORCID: 0000-0002-2539-1736

Szczecin, Poland

\title{
Subjectivity in Caring for the Human Condition. Existential Ideas of Paul Tillich as an Inspiration for Pedagogy
}

\author{
Podmiotowość w trosce \\ o kondycję czlowieka. Egzystencjalne tropy \\ Paula Tillicha jako inspiracje dla pedagogiki
}

\begin{abstract}
Summary: The article discusses the issue of subjectivity in caring for the valuable existence of the individual. While following the ideas of Paul Tillich, I appeal for a widening of the interpretation space in pedagogical thought, by applying concepts from outside the canon's framework. The use of Tillich's analysis helps to affirm the autonomy of a person, with their centrality, and the right to remain unaffected by the pressure of collective conventions; this contributes to self-actualization and happiness. The examination of views by the great Protestant humanist Paul Tillich is extremely important and much needed for pedagogy, as it inspires the shaping of existential sensitivity in the course of formation and education, while taking care of individuals.
\end{abstract}

* Dr hab. Julita Orzelska - assistant professor at the Institute of Pedagogy, at the University of Szczecin. Address: Ogińskiego 16/17 Street, 71-431 Szczecin, Poland; email: jorzelska@wp.pl. 
Keywords: polarity of human condition; concern; human potential; essence of humanity; despair as the courage of being.

Streszczenie: Tekst dotyczy podmiotowości w trosce o wartościową egzystencję człowieka. Unaoczniając tropy z odczytu dzieł Paula Tillicha upominam się o poszerzenie przestrzeni interpretacji w myśleniu pedagogicznym o koncepcje spoza ram ujętych jako kanoniczne. Wykorzystanie analizy prowadzonej przez Tillicha służy upomnieniu się o autonomiczność osoby mającej swoją podmiotowość i prawo do nieulegania presji konwencji zbiorowych, co sprzyja samorealizacji i szczęściu. Zmierzenie się z myślą wielkiego humanisty protestanckiego Paula Tillicha jest niezwykle istotne i potrzebne dla pedagogiki, stanowi bowiem inspirację dla kształtowania wrażliwości egzystencjalnej w toku wychowania i edukacji w trosce o człowieka.

Słowa kluczowe: biegunowość kondycji człowieka; zatroskanie; potencjalność człowieka; esencja człowieczeństwa; rozpacz jako męstwo bycia.

The motivation to trace the thoughts of a distinguished Protestant theologian, Paul Tillich, stems from a belief that in Poland the tradition of Protestant theology, including its most valuable concepts, has not been duly accepted. This might result from the fact that the Christian pedagogy is mainly associated with achievements based on the predominant Catholic tradition, as seen today from the viewpoint of Neo-Thomism. By highlighting issues that extend beyond the dominant framework of the doctrine, I am convinced that pedagogy, with its existential sensitivity, might greatly benefit from including concepts from outside the mainstream narration. Thus, it can extend the space for interpretation, which carries huge potential for pedagogical thinking. The task of determining important answers for pedagogy can be implemented independently of the intentions of this article, as it emerges from the typology of pedagogically valuable narrations proposed by Zbigniew Kwieciński, and the first attempts to apply it (i.e. the illustration of "symbolic benefit") in Monika Jaworska-Witkowska's reconstructions. ${ }^{1}$ The use of Tillich's intentional analysis of systematic theology, as well as a skilful translation of the underlying thought into pedagogy beyond references to faith, supports a thinking that is free from intentional restrictions, whose spe-

${ }^{1}$ Cfr. Monika Jaworska-Witkowska, Zbigniew Kwieciński, Nurty pedagogii (Kraków: Impuls, 2011). 
cific nature appears to be only apparent. As a wise theologian with remarkable depth of insight, Tillich offers many valuable thoughts that open horizons for understanding humans and the world. The reference to various currents of reflection and creativity in the humanities, which reflect autonomy in the approach to human existence, appears to be crucial for thinking about the individual; so too is the autonomy of a person, with their subjectivity and the right to remain unaffected by the pressure of collective conventions, and their search for self-actualization and happiness. The value of Tillich's work is confirmed through the existence of many scientific works around the world, which are translated into many different languages; their authors, as researchers of the theologian's thoughts, show that Tillich's work has been underestimated in terms of creating the fundamentals of human existence. ${ }^{2}$

Addressing the development of those ideas included in the works of the great Protestant humanist Paul Tillich ${ }^{3}$ seems to be very important, indeed necessary for pedagogy. ${ }^{4}$ This theological reflection is rooted in previous rich and deep philosophical reflection, which includes ontological and epistemological perspectives. Therefore, it provides general answers that are important for developing existential sensitivity during the course of individuals' formation and education.

\section{Existential concerns}

The category of "concern" that Paull Tillich highlights, when referring to the existence of humans as "encompassing the structure, sense and pur-

${ }^{2}$ Cfr. David H. Kelsey, "Paul Tillich", in: The Modern Theologians, ed. David F. Ford (Oxford: Blackwell Publishing, 2005), 62-76; Johannes Kubik, Paul Tillich und die Religionspädagogik (Göttingen: V\&R unipress, 2011); Bernard Martin, The Existentialist Theology of Paul Tillich (New York: Bookman Associates, 1963); Wilhelm Pauck, Marion Pauck, Paul Tillich: His Life and Thought (Eugene, OR: Wipf and Stock Publishers, 2015); Nimi Wariboko, Amos Yong, Paul Tillich and Pentecostal Theology: Spiritual Presence and Spiritual Power (Bloomington, IN: Indiana University Press, 2015); Gunther Wenz, Subject und Sein. Die Entwicklung der Theologie Pauls Tillichs (München: Kaiser, 1979).

${ }^{3}$ Cfr. Paul Tillich, Męstwo bycia, trans. Henryk Bednarek (Poznań: Rebis, 1994); Paul Tillich, Teologia systematyczna, vol. I-III, trans. Józef Marzęcki (Kęty: Wydawnictwo Antyk, 2004-2005).

${ }^{4}$ Of course, there were initial attempts at similarly oriented understanding, cfr. Ryszard Kozłowski, "Kondycja człowieka w perspektywie filozofii męstwa Paula Tillicha”, in: Kondycja człowieka współczesnego, ed. Czesława Piecuch (Kraków: Wydawnictwo TAiWPN Universitas, 2006), 281-292. 
pose of existence", ${ }^{5}$ is crucial for thinking about mankind. The awareness of possible threats and worries about things being easily lost, are intertwined with a great concern to preserve the significance of existence ("to be or not to be"), which indeed triggers people's potential commitment, goodness, and understanding of the seriousness of being. While highlighting concerns about the existence of an individual, Tillich refers to particular daily concerns, and stresses "definite concern", understood as worrying about finite and universal affairs (life, death, sense, holiness, fate, etc.). ${ }^{6}$ This signifies the tension between the two extremes that force us to be vigilant in life, which is expressed by "oscillating between conditional, fragmented and finite situations and experiences and moments when we are overwhelmed by the question about the meaning of existence."

Tillich sensitizes us to the "idolizing" attitude and excessive attachment to one of the poles of concern, while we neglect what exceeds the horizons of our imagination and existential vigilance. The weakness of this approach is evident in the case of a dramatic collapse of identity in extreme situations; or, on the contrary, when spiritual elevation makes us cease to recognize everyday life requirements. The elevation of a particular object of concern makes our existence limited, and deprives us of safety valves when we face specific matters that pose universal challenges, such as questions about the meaning of life in the face of trauma. Thus, Tillich provides recognition of the need to develop an attitude that conveys a "fully existential concern about man", ${ }^{8}$ i.e. which considers living one's life as the foundation and protection against "self-perdition and alienation".

Tillich draws attention to the need to develop an attitude of experiencing that involves being concerned about what we encounter cognitively. In its philosophical sense, this means the influence of "philosophical eros", or being hungry for experiencing; whereas in the case of theology, it concerns "involvement in the content" which has an existential nature. Tillich describes this as follows, in relation to attitudes of theologians: "He is connected to all his existence, with its finite nature and concern, with his internal contradictions and his despair, with healing powers embedded in him and in his social

\footnotetext{
5 Tillich, Teologia, vol. I, 21.

${ }^{6}$ Ibidem, 19.

7 Ibidem, 20.

${ }^{8}$ Ibidem, 24.

9 Tillich, Teologia, vol. II, 61.
} 
situation." ${ }^{10}$ I would like to emphasize that in the case of a teacher, the equivalent of a theologian's faith is the reference to humanist concerns regarding the good of the other man; opportunities for developing a new subjectivity; sharing experiences and concerns; and providing development potential in culture.

While highlighting Tillich's attitude to culture, in terms of its relationship with human existence as a challenge to humanity, it is worth mentioning that this great Protestant humanist shows sensitivity to the "new approach to the normative nature of institutional history". ${ }^{11}$ In his case, this approach is the Church; and for us, it also includes broad secular institutions, such as schools or education. Tillich looks for an intermediate road between on the one hand, institutional absolutism, which regards decisions made by institutions and their authorities in history as "not only the source but also a current standard", which is unconditionally valid; and on the other, a radical refusal to recognize any normative power of institutional expectations, which are always only historical claims. ${ }^{12}$

The fundamental idea, which is pedagogically significant and developed by Tillich in volume III of his treatise, is his philosophy of culture, based on the thesis that "the purpose of culture is the actualization of human potential as the carrier of the spirit". ${ }^{13}$ At the same time, we may note a clarification resulting from the recognition, which is valid in relation to education and culture, that "due to the human finite, no one is capable of satisfying the humanistic ideal" of achieving full actualization, since it always occurs in "terms of historical destination"; although it would be more appropriate to point to historical and social conditions which can be challenged, but which also have an impact on "decisive human potentials that always remain unrealized" ${ }^{14}$ Culture is not, as Tillich rightly stresses, an issue of exclusivity, but a space for each person in their relationship with the world. ${ }^{15}$

An important issue is Tillich's acceptance of the significance of the coupling between the "polarity of the self and its world", in circumstances such as people being "attached to their environment". Furthermore, "man has the

\footnotetext{
10 Tillich, Teologia, vol. I, 29.

11 Ibidem, 54.

12 Ibidem.

13 Tillich, Teologia, vol. III, 83.

14 Ibidem, 84.

15 Ibidem; cfr. Kelsey, "Paul”, 63-64.
} 
environment, but he has it as part of the world", ${ }^{16}$ and at the same time he is capable of extending beyond the environment. Sometimes, however, it happens that "man becomes a limited 'I', dependent on the limited environment. Man loses his world; and has only his environment." 17 The opposition between the human world and human environment is essential, if an individual is not to be held hostage to this particular social position.

Man is able to go beyond each environment in the direction of his world. Only the loss of his own world subjects him to captivity of the environment, which in reality is not his environment, but the result of a creative encounter with his world, represented by a fraction of the world. The real environment of man is the universe, and any specific environment is eligible as a sector of the universe. Only in alienation can a man be described as a normal object of environmental impacts..$^{18}$

This reveals the importance of Tillich's concern about the need to prevent an individual from being held hostage to his finite, transient entanglement in his own surroundings; rather, he wants a person to reach out and actuate his capacity to participate as widely as possible in the world; this prevents him from being closed and deprived of access, beyond historically and socially available content. It is a precondition that concerns about existence are entangled with the readiness to enact burdensome "self-transcendence". This "act of losing oneself" in existence, deprived of concerns about one's own essence of humanity, is coupled with the process that is described as "losing one's world in alienation". ${ }^{19}$

\section{Polarity of the human condition}

The starting point is to distinguish fundamental existentially important features, including functions, which, according to Tillich, comprise the definition of life as the "actualization of potential". ${ }^{20}$ It is associated with various "polarities" that must be described in terms of dependencies and tensions in

\footnotetext{
16 Tillich, Teologia, vol. II, 62.

17 Ibidem, 63.

18 Ibidem, 63-64.

19 Ibidem, 61.

20 Tillich, Teologia, vol. III, 35.
} 
typical relations. Those relations are applicable to three basic life functions: self-integration, self-creation, and self-transcendence; these are entangled in dualities: "Individualization and participation", "dynamics and form" and "freedom and destination". ${ }^{21}$ These and other aspects of Tillich's analyses are components of the theory in a context much wider than the theological one. Therefore, they are a fascinating description of the relational complexities that need to be taken into account in the humanities, regardless of their orientation in the sphere of faith.

This "polarity" has been illustrated by Tillich in different ways that are instructive for pedagogy, in the context of subjectivity being understood as giving an opportunity to trigger one's own potential. An important example in the treatise is the relationship between "specificity" and "versatility", which seen in a polarized manner may become even "oneness", provided we do not forget that "something that is simply particular has limited concreteness, as it must exclude other particular realities". ${ }^{22}$ Tillich looks at the typical "tension between the universal and the specific", which often leads in theology to harmful divisions between separate disciplines. Thus, we lose the possibility of their unity, and even the perception of ties between them. ${ }^{23}$ Therefore, we forfeit the necessary minimum "dialectical thinking", in which the opposite poles "postulate each other". ${ }^{24}$ We have here an accent on the perspective that understands the "correlation" not only as a "compatibility of different series of data", but also as a "logical relationship of concepts as in polar relations. It can also mean the real relation of things or events in structural entities". ${ }^{25}$ The perception of a so-conceived correlation is an important methodological postulate of Tillich's systematic analyses; this is applicable to the whole of human existence, and expresses concern about the perception of interactions between poles or dimensions that remain in those reciprocal relations. It is necessary, therefore, to reject the perspective and method "which can be called 'dualistic", i.e. making an extreme split between poles, as well as the viewpoint that operates by "avoiding the split". ${ }^{26}$ Neither a recognition of the extreme split, nor a disregard for the necessity of the split between poles which remain in permanent tension within the complex whole, can be

\footnotetext{
${ }^{21}$ Ibidem, 37.

22 Tillich, Teologia, vol. I, 23.

${ }^{23}$ Ibidem, 34.

24 Ibidem, 58.

25 Ibidem, 62.

${ }^{26}$ Ibidem, 66.
} 
considered the appropriate approach to the complexity of existential phenomena. This complexity arises from the tension between the existence and the essence, which forces the duality of the analysis.

In so far as the human existence shows internal contradiction or alienation, we need to consider it twofold: on the one hand, we need to deal with a man as he essentially is (and should be), and on the other hand, we deal with what he actually is in his alienated existence (and should not be). ${ }^{27}$

Tillich's thesis that, ontologically, an individual is a being dually spread between "self-actualization" and "self-transcendence", and that a man should not be brought to one of the poles because he loses other aspects of the "polarity" of the human condition (e.g. entanglement in the tension between the finite and the infinite, between the ready and what is becoming ready), reveals the complexity and depths of thinking about a person and his potential to extend beyond himself.

According to Tillich, the poles of the tension (between self-actualization and self-transcendence) should be perceived at the same time as the inalienable parts of the whole, which develops its unity and fullness in the continuous dual coupling. This reveals his vision of the human condition, which is crucial for humanistic thinking about mankind.

\section{Despair as the courage of being}

Tillich's sensitization of the individual to his existence while taking care of his good shows the subjectivity of the new perspective. Tillich's position regarding despair is in many ways fascinating and informative, and provides inspiration for pedagogy, as opposed to typical associations that often lose the sense and complexity of the phenomenon of human despair. Tillich sees despair as a differentiated phenomenon that paradoxically conveys a positive aspect, contrary to the most common attitude, of manifesting the escape strategy. It is not the despair of man that is in itself existentially worrying, but the blindness to its importance within the being of mankind. Thus, a lack of despairing gestures in human life - if we follow Tillich's thinking - should be considered worrying. Tillich's considerations pertaining to the "experi-

27 Ibidem, 67. 
ence of general breakdown of the sense" in social space are particularly important for a pedagogue, in the context of concern for human subjectivity.

Paradoxically, Tillich's diagnosis of the mid-20 $0^{\text {th }}$ century condition now appears to be more relevant, justified and dramatic. In his understanding of existentialism, we must be concerned about collective experience, and our forms of reacting to experiences should not focus on melancholy, upswings, or other manifestations of individualism. The same applies to despair as an existential phenomenon, from the point of view of the human condition. This in fact applies to forms of collective reactions to deep spiritual alienation, and even the mere perception of the alienating reality, which annihilates on a wider scale the sense of human existence and understanding of the world. The presence of despair becomes evidence for the perception of the drama; whereas blindness to it, and therefore the lack of despair (and its replacement with various more or less liberated forms of social indifference) would be an even stronger sign of the fall of humanity.

The twentieth-century man has lost a meaningful world and self and lives among meanings outside the spiritual center. The man-created world of objects has drawn into itself he who created it and who now loses his subjectivity. Man has sacrificed himself to his own productions. But man is still aware of what he has lost or is constantly losing. He is still man enough to experience his dehumanization as despair. He does not know the way out but he tries to save his humanity by expressing the situation as without an "exit". He reacts with the courage of despair, the courage to take his despair upon himself and to resist the radical threat of nonbeing by the courage to be as oneself. ${ }^{28}$

Tillich describes the phenomenon by referring to artists' and intellectuals' attempts at a creative presentation of the situation, and he sensitizes us to different attitudes and reactions to such presentations. Despair applies to and is revealed both at the level of phenomena that trigger it, and also when we deal with collective opposing reactions to such attempts. Such attempts treat these presentations as incidents of the same nature, which in turn are often treated as additional escalating reasons for despair that require even stronger opposition. In art, practices of showing reasons for despair may themselves be treated as a reason to mobilize despairing gestures of rebellion. Then, we witness not only a splitting of the directions in which despair is expressed

28 Tillich, Męstwo, 152-153. 
(until despair protests against attempts at a despairing attitude), but also various restrictions of these attitudes. Tillich describes this as the courage to be "like parts" that fail the existential challenge, where the scale of the desperate call to oppose the degradation of hopelessness is different from the desperate rebellion against the unveiling of the degradation itself.

Every analyst of present-day Existential philosophy, art and literature can show their ambiguous structure; the meaninglessness that drives to despair, a passionate denunciation of the situation, and the successful or unsuccessful attempt to take the anxiety of meaninglessness as to the courage to be oneself.

It is not astonishing that those who are unshaken in their courage to regard themselves as a part, either in its collectivist or its conformist form, are disturbed by the expressions of the Existentialist courage of despair. They are unable to understand what is happening in our period. They are unable to distinguish the genuine from the neurotic anxiety in Existentialism. They attack as a morbid longing for negativity what in reality is courageous acceptance of the negative. They call decay what is actually creative expression of decay. They reject as meaningless what is the meaningful attempt to reveal the meaninglessness of our situation ${ }^{29}$.

Tillich emphasizes that creative presentation, which critically reveals decadence, does not have to be subjected to the accusation of decadence. However, we need to understand the origin of such collective interpretative hysteria, or neuroticism. An individual may defend himself by an "escape from freedom", i.e. what brings him the sense of danger and suppresses his subjectivity, and which may also include manifestations of warnings against sources of the threat, which themselves produce new symptoms that threaten the sense of security. We may witness the prevailing attitude resulting "from the desire to protect the self-restraining courage of regarding themselves as a part", since revealing it in full does not give the sense of security. Therefore, the individual is incapable of coping with it, and as Tillich further stresses, "he must damp the willingness to accept existentialistic visions" 30 as dangerous in themselves; in accordance with the principle, it is only seemingly logical that showing pathology increases its presence in space it threatens.

\footnotetext{
${ }^{29}$ Ibidem, 153.

${ }^{30}$ Ibidem, 153.
} 
In the case of a person who is not ready to accept these sources of despair, and also unprepared to combat them, Tillich claims that "one even enjoys them if they appear in the theatre or in novels, but one refuses to take them seriously, that is as revelations of one's own existential meaninglessness and hidden despair." ${ }^{31}$

Tillich, whose various theoretical reflections repeatedly refer to the achievements of psychology (including psychology of depth, psychoanalysis, and psychotherapy), considers the causes of the sense of threat that results in aggression against those who try to indicate the objects or phenomena that arouse concern; they are even alarmingly recognized as a threat to the condition and subjectivity of man. Not without reason, Karen Horney referred to growing neuroticism as the phenomenon of our times. Tillich's conclusion results from a viewpoint that is apparently linked with that fact that the desperate attitude is a defence mechanism against despair in itself, which actuates various defence mechanisms, and is dominated by extreme measures:

But man does not feel spiritually threatened by something that is not an element of oneself. And since it is a symptom of the neurotic character to resist nonbeing by reducing being, the Existentialist could reply to the frequent reproach that he is neurotic by showing the neurotic defence mechanisms of the anti-Existentialist desire for traditional safety. ${ }^{32}$

As pedagogy is sensitive to existential attitudes and their development, it cannot ignore a thorough examination of phenomena embedded in the psychological reflection and research on humanity, in the category of "defence mechanisms"; or their dramatic elaboration, which is mostly applicable to measures providing an illusory and dangerous sense of security, sense of value, sense of personal community, sense of purity and fidelity - to mention some of components of the necessary illusion.

From the perspective of education, important considerations by Tillich on the "courage of despair" relate to the attitude of the Church, and the ability to distinguish courage in the interests of the whole human existence. They also deal with fanatical courage, which refers to being "as a part", and thus ensures partial comfort; while people desperately fight to prevent unbearable threats from being seen, especially given that despair would have to include

\footnotetext{
${ }^{31}$ Ibidem, 153-154.

32 Ibidem, 154.
} 
consent that the attitude of the fighters themselves contributes to despair. It is worth quoting remarks of the great theologian in full, since it is difficult to find such deep and uncompromising references to often subconscious and even nullified spiritual and institutional obligations, expressed with a clear ethical and pedagogical dimension.

There should be no question of what Christian theology has to do in this situation. It should decide in favour of truth rather than safety, even if safety is consecrated and supported by the Churches. Certainly there has been a Christian conformism from the beginning of the Church onwards, and also a Christian collectivism, or at least semi-collectivism, in several periods of Church history. But this should not induce Christian theologians to identify Christian courage with the courage to be "as a part". They should realize that the courage to be as oneself is the necessary corrective to be as a part - even if they rightly assume that neither of these forms of the "courage to be" gives the final solution. ${ }^{33}$

The issue is not about theological disputes, of course, but about the concern regarding the philosophical reflection on human existence in the contemporary society, from the viewpoint of efforts to provide content for pedagogical reflection and educational practices at various levels and forms (for both children and adults), and helping them to avoid prevalent mistakes and traps, while taking care of subsequent generations, and the future of humanity in its mutual relations in our diverse and still globalizing world.

\section{Conclusions}

Paul Tillich postulates the pedagogy of spiritual partnership, which respects saturation with caring for existence in its spirituality, subjectivity and intentionality. It also highlights feedbacks for the development of humanity, as it is entangled in the complexities of human existence, which is subjected to deep reflection. The validity of the great theologian and humanist's consideration on sensitivity to individual and collective existence makes him a unique contemporary pedagogue. Thus, it highlights the issue of the development of pedagogy, which gradually opens itself to ideas that combine caring for human existence and the use of various cultural inspirations; these

${ }^{33}$ Ibidem. 
inspirations often cannot be brought closer together, but can learn from each other. The ideas pertaining to the care of mankind, and the existential sense of the courage of being, open ample opportunities for developing a pedagogical attitude that is mature enough to meet challenges. The care of existential interactions, while developing subjectivity and stimulating the human potential, requires us to be open to inspiration from other areas of the humanities and cultural reflection. The study of Paul Tillich's thought opens us to the interpretation of "content not present" in the thinking which is sensitive to humanity.

\section{References}

Jaworska-Witkowska, Monika, Zbigniew Kwieciński. Nurty pedagogii. Kraków: Impuls, 2011.

Kelsey David H. "Paul Tillich". In: The Modern Theologians, ed. David F. Ford, 62-76. Oxford: Blackwell Publishing, 2005.

Kozłowski, Ryszard. "Kondycja człowieka w perspektywie filozofii męstwa Paula Tillicha". In: Kondycja człowieka wspótczesnego, ed. Czesława Piecuch, 281-292. Kraków: TAiWPN Universitas, 2006.

Kubik, Johannes. Paul Tillich und die Religionspädagogik. Göttingen: V\&R unipress, 2011.

Martin, Bernard. The Existentialist Theology of Paul Tillich. New York: Bookman Associates, 1963.

Pauck, Wilhelm, Marion Pauck. Paul Tillich: His Life and Thought. Eugene OR: Wipf and Stock Publishers, 2015.

Tillich, Paul. Męstwo bycia, trans. Henryk Bednarek. Poznań: Rebis, 1994.

Tillich, Paul. Teologia systematyczna, vol. I, trans. Józef Marzęcki. Kęty: Wydawnictwo Antyk, 2004.

Tillich, Paul. Teologia systematyczna, vol. II, trans. Józef Marzęcki. Kęty: Wydawnictwo Antyk, 2004.

Tillich, Paul. Teologia systematyczna, vol. III, trans. Józef Marzęcki. Kęty: Wydawnictwo Antyk, 2005.

Tillich, Paul. Era protestancka, trans. Jacek Aleksander Prokopski, Nadija Łomanowa-Barańska. Kęty: Wydawnictwo Marek Derewiecki, 2016.

Wariboko, Nimi, Amos Yong. Paul Tillich and Pentecostal Theology: Spiritual Presence and Spiritual Power. Bloomington, IN: Indiana University Press, 2015.

Wenz, Gunther. Subject und Sein. Die Entwicklung der Theologie Pauls Tillichs. München: Kaiser, 1979. 
